Macarena de la Vega

Figure 1. Cover of Henry-Russell Hitchcock's Modern Architecture: Romanticism and Reintegration, reprint of 1993.
Macarena de la Vega. Architect. Master Degree UPM. PhD student University of Canberra. Member of the Centre for Creative and Cultural Research.

\title{
A historical legacy: Henry-Russell Hitchcock and early Modernism
}

Key words: Henry-Russell Hitchcock, historiography, Modern Architecture, Modern Movement.

On the occasion of the publication of Modern Architecture: Romanticism and Reintegration's first Spanish edition. This essay aims to discuss the impact of HenryRussell Hitchcock's book - published in 1929- on the history of architecture. In spite of being the first history of modern architecture written in English, Modern Architecture fell into oblivion due to the success of Hitchcock's subsequent book, coauthored with Philip Johnson: The International Style: Architecture since 1922. Discussing the critical approaches to the text -from the first book reviews to the latest historiographical studies- brings to light Hitchcock's contribution to the historiography of modern architecture.

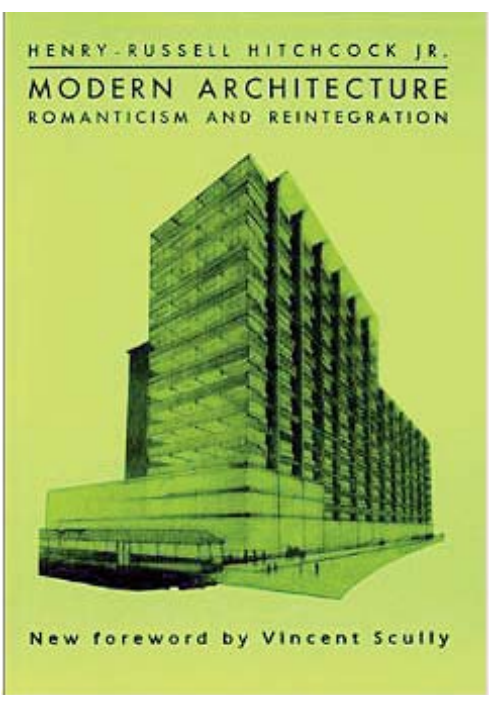

"Modern Architecture ha[d] the good fortune to be practically the only general history in English of the development of recent and contemporary architecture, a good fortune that naturally makes it a work of importance". (Egbert 1930: 98-99)

$M$ odern Architecture: Romanticism and Reintegration written by HenryRussell Hitchcock in 1929 is the first history of modern architecture. Moreover, until just recently Modern Architecture was the only history of modern architecture available exclusively for the English-reading audience. The lack of interest, at least among publishers, was the result of the success of Hitchcock's subsequent book, The International Style: Architecture since 1922 (1932). It will be argued in this paper that the content of Modern Architecture -at least regarding the new architecture- was not the differentiating factor between this book and The International Style. One of the great advantages of The International Style over Modern Architecture was the prestige of the Museum of Modern Art as a book publisher. This contrasts with the smaller but relevant, also New Yorker, publisher of Modern Architecture, Payson $\&$ Clarke. The aim of this paper is to provide an account of the historiographical significance of the result of Hitchcock's "long journeys and European friendships", Modern Architecture: Romanticism and Reintegration (Stonorov 1930: 586). This essay will examine and discuss different readings that several authors have done of the text, from the first reviews published in 1930 through the most recent historiographical studies (figure 1).

The lack of interest in Modern Architecture also had consequences in its editorial life. The book was reprinted over forty years after its publication, first in 1970 and then, in 1972. The last reprint appeared in 1993 with a prologue written by Vincent Scully. All of the publishers of these reprints were small in comparison to the Museum of Modern Art. Surprisingly, the book has just recently raised interest in foreign publishers: it has been translated into Italian and it is currently being translated into Spanish. ${ }^{1}$ On the one hand, the new editions have reengaged Hitchcock's book with contemporary architectural discourse. On the other hand, it's possible impact has been lessened by the fact that for a long time it was only available in English. The historiographical interest in Modern Architecture may be increased now with the first translations into other languages.

\section{"The Age of Romanticism" versus "The New Pioneers"}

Modern Architecture was reviewed not only at the time of its publication, but also in the 1970s and 2000 after its subsequent reprints. In 1930, Donald D. Egbert criti- 
cised Hitchcock's discussion of 'The New Pioneers' because it "reduces its [the book's] value as architectural history" due to his "enthusiasm", "dogmatism", "dilettantism" and even "partisanship" (1930: 9899). Egbert's criticism focuses on the book as a whole, emphasising Hitchcock's lack of unity and lack of adequate illustrations of the buildings referenced. However, praise can also be found in this review. According to Egbert, "by far the best parts of Modern Architecture are those earlier chapters on Romanticism and "The New Tradition" in which the character of a manifesto is lacking and in which the author is thus able to survey the field under consideration in a more detached and objective manner" (1930: 98). The objectivity of Hitchcock's approach is an issue that has played an important role in the latest historiographical studies, discussed below.

Also in 1930, Oscar G. Stonorov defined the study as a "clever analysis" and emphasised the significance of the last part of the book. "Seldom has the movement of 'The New Pioneers' (...) been shown with such clear relation to the past, rarely is the background of European architecture better explained" (1930: 586). Stonorov draws attention to two important features: first, the use of new language to most historians at that time; and, second, the valuable bibliographical notes added to the text, which were very up-to-date.

On the occasion of Modern Architecture's republication, it was again reviewed. In 1974 Walter Segal suggested Modern Architecture a piece of writing of the past; it "offers more to the historian than to the contemporary reader" (1974: 66). In Segal's opinion Hitchcock's classification of "The Age of Romanticism", "The New Tradition" and the "The New Pioneers" should be regarded as a historical document. Although a reflection of its time, the book's structure and the conclusions reveal the weaknesses of Hitchcock's choices and positions. John Wilton-Ely reviewed Modern Architecture in 1976 together with three other books, two of which were republications of Nikolaus Pevsner's books. One of Wilton-Ely's aims was to discuss the book in reference to the continual reassessment of the historiography of modern architecture while reflecting the attitudes and criteria in contemporary design. The four books "represent some of the key phases in this revisionary process" (1976: 419). Contrary to Egbert and similar to Stonorov, Wilton-Ely not only considered "The New Pioneers" fascinating and per- ceptive, but also disregarded "The Age of Romanticism" as unsuccessful in tracing the historical roots of modern architecture.

In 2000 Paolo Scrivano reviewed both Modern Architecture and The International Style on the occasion of the republication of these two seminal books. While previous reviewers focused on the sections of the book, Scrivano introduced the issue of the theoretical framework of Hitchcock's writings: humanism. The philosophy of New Humanism, according to the Italian scholar, defended the need to relate moral content to the artistic work:

"The many cultural references in both Modern Architecture and The International Style are valuable not only for deepening Hitchcock's own arguments, but for offering a rich range of thinking: his citations of Maritain, Spengler, and the French philosopher Julien Benda (whom he frequently invokes in his critique of Babbit) are much more than erudite references. They show the attention that Hitchcock gave to the crisis of rationalism in twentieth-century culture in general before he applied it to architecture. Perhaps more than institutionalising modern architecture, his books anticipated its decline. This hypothesis alone invites a new reading of his books". (Scrivano 2000: 80-83)

A number of historians and theorists have reviewed Modern Architecture since its publication and republication. Some argued that the most valuable contribution of Hitchcock's work was his outline of "The Age of Romanticism", whereas others believed that to be his discussion of "The New Pioneers". Hitchcock's objective discourse and his theoretical framework were highlighted in Modern Architecture's reviews discussed above and became matter of further discussion. Hence, following Scrivano's criteria, republication begs for rereading. And that is precisely what several scholarly studies have attempted, especially since 1980 .

\section{A tribute to history}

Two of the studies on the history of architecture published before Hitchcock's death in 1987 will be examined below. In The Rise of Architectural History, David Watkin declared that Modern Architecture: Romanticism and Reintegration was the result of twenty years of the flowering of the American tradition of art history. Responsible for that development were the historians: Fiske Kimball, Lewis Mumford, Meyer Schapiro, Vincent Scully, Carroll 
Meeks, Donald Drew Egbert (author of the book's first review), the transplanted Europeans Erwin Panofsky and Paul Frankl and, finally, Henry-Russell Hitchcock. It is Watkin's belief that "one of the most influential of American-born architectural historians is Henry-Russell Hitchcock (...). Everything he writes is thorough and workmanlike, though lacking in the kind of conceptual or intellectual interest which characterises the work of German-inspired art historians" (1980:41). Watkin's assertion contrasts with Scrivano's discussion of Hitchcock's humanism and the cultural references of his writing. However, Watkin is not the only one to consider Hitchcock's lack of a strong theoretical framework (figures 2 and 3).

The architectural historian Helen Searing compiled a tribute to Henry-Russell Hitchcock in 1982. In the preface Philip Johnson, the co-author of The International Style, said that, at that time, Hitchcock was "the leading historian of architecture in the world" (Searing 1982, vii). Searing establishes in her essay that the distinction between "The New Tradition" and "The New Pioneer" related to the dichotomy between modern (contemporary) and modernist (radical). Searing is among the scholars who presented Modern Architecture as a precedent for other histories which "dispose with all references to buildings constructed much before 1890" (Searing 1982, 9). In this tribute, Vincent Scully wrote an essay on The New Tradition, which was identified as a 'mode' within modern architecture even more significant than The New Pioneers. It is Scully's belief that "in 1929, Hitchcock was able to preserve a balance of judgement between the ruthless revolutionary and the more traditional points of view, although his term, "The New Pioneers", was, especially for an American, emotio-
Right. Figure 3 Searing's In Search of Modern Architecture: A Tribute to HenryRussell Hitchcock, 1982. nally weighted enough" (Searing 1982, 10). Scully drew a surprising link between The New Tradition and Post-Modernist architectural theories.

"It therefore follows that Hitchcock, himself a Pioneer in the establishment of the International Style, also acted as an historical precursor of what has come to be called Post-modernism which might in this instance be described as the resurrection of that New Tradition which had been perceived in his earliest works". (Searing 1982, 13)

Similar to the debate aroused by the book reviews, these essays emphasized the significance of methodological labels, or "modes" as Scully called them, established by Hitchcock: "The Age of Romanticism", "The New Tradition" and "The New Pioneers". It can be argued that for Searing and Scully it was also necessary to explain and define notions such as "modern", "modernist" and "pioneer" in order to fully understand Hitchcock's proposal. However, the main novelty comes from Scully's essay, which argues that the primary contribution of Hitchcock's Modern Architecture is neither "The Age of Romanticism" nor "The New Pioneers": it was "The New Tradition". Scully, surprisingly, defends the position that the architecture of "The New Tradition" can be understood as a precedent for PostModernism, although Scully fails to develop this relationship more fully. Both Searing and Scully wrote essays on Hitchcock's work after his death in 1987, along with other scholars exploring the field of the historiography of modern architecture.

\section{Hitchcock in the Historiography of Modern Architecture}

Since the death of Henry-Russell Hitchcock, his work has been discussed mainly within the fields of architectural history in America and the historiography of modern architecture. In a more recent essay, "Henry-Russell Hitchcock: The Architectural Historian as Critic and Connoisseur" (1990), Searing regarded Modern Architecture: Romanticism and Reintegration as a comprehensive monograph, as his unwritten doctoral dissertation, and as the culmination of the earliest phase of Hitchcock's published oeuvre. Searing agrees with Watkin and, as discuss below, with the architect and historian Gevork Hartoonian in recognising Hitchcock's lack of interest in architectural theory. "But he was not ignorant of it. (...) Nor did Hitchcock's lack of interest in 
Figure 4. Cover of Elisabeth Blair MacDougall's The Architectural Historian in America, 1990.

Figure 5. Cover of Panayotis Tournikiotis' The Historiography of Modern Architecture, 1999. theory per se mean that he was not concerned with ideas" (Searing 1990, 258259). At the end of the essay, Searing discussed Hitchcock in contrast to Nikolaus Pevsner and Sigfried Giedion, in a manner similar to Hartoonian. "Pevsner and Giedion were writing polemical surveys of modern architecture that are teleologically determined to end up in the orthodox movement. Hitchcock had no such intention” (Searing 1990, 263) (figure 4).

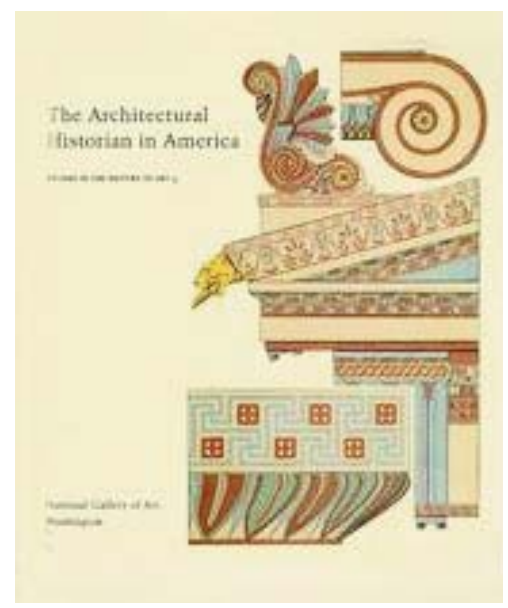

In 1992, Scully wrote the foreword to the Da Capo reprint of Modern Architecture: Romanticism and Reintegration. In contrast with Walter Segal (one of the book's reviewer), Scully argued that "everything jumps out of the page afresh, as if it had been written only yesterday" (Scully 1993, v). In his essay, Scully unfolds Hitchcock's alleged aversion to the subject of urban. "And here Hitchcock's greatest, almost fatal, weakness as a critic shines forth. He will not deal with city planning or with the building of cities, or with architecture as the construction of the human environment or, most of all, of the human community" (Scully 1993, ix). In the discussion about the most significant part of Hitchcock's book, Scully positioned himself for "The New Tradition" and understood it to be more permanent than "The New Pioneers" (figure 5).

Panayotis Tournikiotis included Hitchcock in the "corpus" of works he examined in the seminal The Historiography of Modern Architecture. Despite the fact that he discusses Hitchcock in the fourth chapter, according to Tournikiotis, Hitchcock "is the first to provide a detailed description in English of the architecture of the first three decades of the twentieth century" $(1999,115)$. Tournikiotis comments on two aspects of the "operative text" or manifesto Modern Architecture: the actual content and his alleged objectivity. He con- firms that there is no difference between the way Hitchcock presents the new architecture in both Modern Architecture and The International Style; the content regarding 'The New Pioneers' is the same in both books. In his opinion, objectivity characterises Hitchcock's discourse "which, thanks to the distance now lying between it and the fields, on which the battles of the interwar period were bought out, is capable of approximating more closely to "the ideal objectivity of the historian", at least where ambition, structure and style are concerned" (Tournikiotis 1999,115-116). Hitchcock's objectivity is also one of the issues studied in Frank Salmon's Summerson and Hitchcock: Centenary Essays on Architectural Historiography and Gevork Hartoonian's The Mental Life of the Architectural Historian: Re-opening the Early Historiography of Modern Architecture (figure 6).

In a 2004 symposium on Summerson and Hitchcock, several scholars presented new research on these two influential history "makers", who wrote in English and contributed to the establishment of the discipline of the architectural history. ${ }^{2}$ According to Frank Salmon, compiler of the symposium proceedings, Hitchcock is a precursor to Peter Collins, Kenneth Frampton and William Curtis. "These books all accept Hitchcock's premise that the origins of 'modern' architecture lay in the middle of the eighteenth century, though not his methodology", characterised by periodization which placed him in the linage of the formalist approach originated by Heinrich Wölfflin (Salmon 2006, $\mathrm{xxx}$ ). In his paper entitled "Romantic Modernity in the 1930s. Henry-Russell Hitchcock's Architecture: Twentieth and Nineteenth Century?", Barry Bergdoll emphasizes two previously considered ideas: first, how Modern Architecture fell

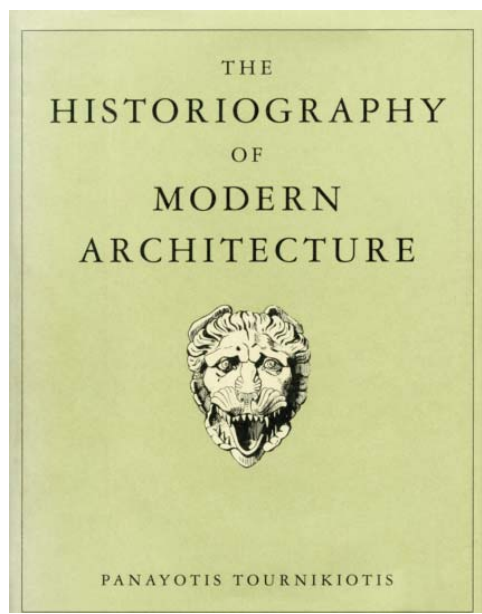


Figure 6. Cover of Frank Salmon's Summerson and Hitchcock: Centenary Essays on

Architectural Historiography, 2006

Figure 7. Cover of Gevork Hartoonian's The Mental Life of the Architectural Historian: Re-opening the Early Historiography of Modern Architecture, 2013.

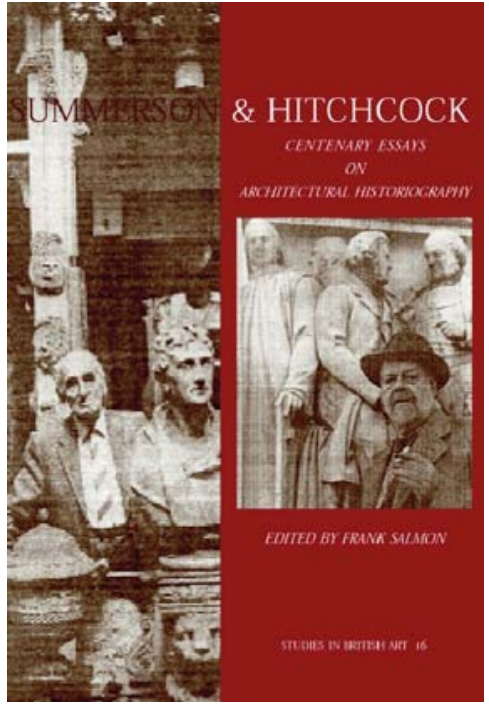

into oblivion due to the success of The International Style (1932), and, second, how the significant division of Modern Architecture in three equal parts is "not coincidental" (Bergdoll 2006, 197). In contrast with Scully, Bergold understand that Hitchcock's alleged aversion to the subject of urban is unwarranted. Hélène Lipstadt defends Hitchcock's objectivity and that Hitchcock's work continues to feed the revisionist historiographical debate. "'An attention to the object to details of architecture that are studied for their own sake,' is often evoked to rebut the charge of formalism that is also often brought against him" (Lipstadt 2006: 338) (figure 7).

The relationship between Hitchcock's writing and architectural theory is also discussed by Gevork Hartoonian in his early historiography of modern architecture. According to Hartoonian, "theory per se was not important to him [Hitchcock]"; he maintained that Hitchcock's "overall view of the early history of modern architecture is devoid of any vigorous theoretical work" (2013: 61, 78). Hartoonian examines Hitchcock's Modern Architecture in terms of periodization, historicism, organicism, regionalism and internationalisation within the explanation of the mental life of the early historians of modern architecture: Hitchcock, Pevsner and Giedion. In this context, he regarded Hitchcock as "one of the first historians to consider geographic differences as an important classificatory mode for the examination of the linguistic multiplicity of modern architecture". (Hartoonian 2013, 66).

\section{Hitchcock's Legacy}

Henry-Russell Hitchcock was the first to pursue important achievements in the dis- cipline of architectural history. He was the first to write, in English, a historical account of the events that led to the rise of modern architecture, after visiting the key countries and buildings himself. For the first time in the historiography of modern architecture, his discourse disregarded the rigid German theoretical framework of the tradition of art history. Pevsner, Giedion and Emil Kaufmann all were formed and influenced by that precise tradition. Hitchcock was the first to outline, in an attempted objective manner, precedents and predecessors of modern architecture, geographically classified, introducing regionalism in the architectural debate. This paper has set out to demonstrate that scholars find it difficult to agree on Hitchcock's most significant contribution to the historiography of modern architecture: "The Age of Romanticism", "The New Tradition" or "The New Pioneers". Contemporary scholars have not come to a consensus on the historiography of modern architecture: neither when was published, nor in the 1970s -and still not even today.

There is even a polemical debate regarding the historicity of Modern Architecture. Some may argue that Hitchcock's work rises from the late 1920s Zeitgeist, and is the result of his positions, while others insist on the contemporary validity and freshness of the text. Similarly, there are different opinions regarding the presence or absence of a strong theoretical framework in Hitchcock's writings.

Any new reprint, or in this case, any edition in a new language, provides the perfect excuse to re-read Modern Architecture: Romanticism and Reintegration and re-discover Hitchcock beyond his role as advocate of The International Style. Beyond his choices and preferences, Hitchcock's attitude and writing style in the first history of

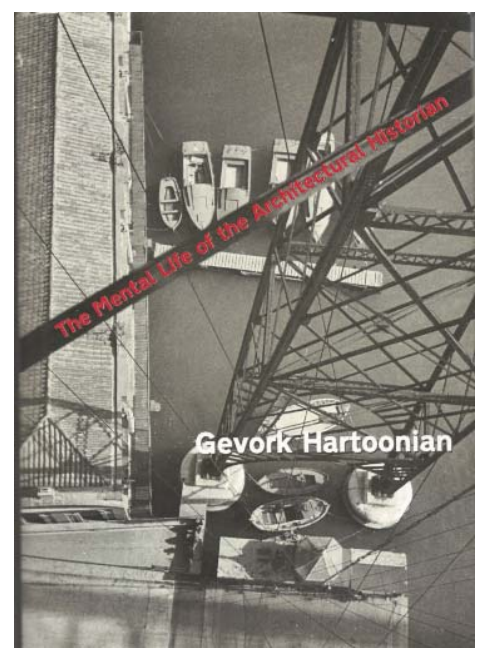


modern architecture is still valid today. "As an historian he had his own perfectly consistent style and method. Each building had to be seen, then turned over and over in his mind till its elements fell into an order significantly related to the historical context...". (Summerson 1987, 4)

\section{Notes}

1. Modern Architecture: Romanticism and Reintegration (New York: Payson \& Clarke, 1929). Reprints: (New York: Hacker Art Books, 1970); (New York: AMS Press, 1972); (New York: Da Capo, 1993) Press, 1993). L'architettura moderna: romanticism e reintegrazione (Bologne: Compositori, 2008). La arquitectura moderna: romanticismo y reintegración (Barcelona: Reverté, 2015).

2. The symposium was entitled 'Sir John Summerson and Henry-Russell Hitchcock: A Centenary Conference on Aspects of Architectural Historiography in the Twentieth Century' and was held in June 2004.

\section{Bibliography}

Bergdoll, Barry. 2006. Romantic Modernity in the 1930s. Henry-Russell Hitchcock's Architecture: Twentieth and Nineteenth Century? In Frank Salmon, ed. Summerson and Hitchcock: Centenary Essays on Architectural Historiography, 193-208. London and New Haven: Yale University Press.

Donald Drew. 1930. Book Review of Henry-Russell Hitchcock's Modern Architecture. Art Bulletin, volume $12, \mathrm{n}^{\circ} 1$ (March): 98-99.

Eggener, Keith L., ed. 2004. American Architectural History: a Contemporary Reader. London and New York: Routledge.

Kruft, Hanno Walter. 1999. Los Estados Unidos en la primera mitad del siglo XX. In Historia de la Teoria de la Arquitectura: desde el Siglo XIX hasta nuestros dias, 717-731. Madrid: Alianza Forma, Madrid, 1990.Original edition: Geschichte der Architekturtheorie, Munich: Beck'sche Verlagsbuchhandlung, 1985.

Hartoonian, Gevork. 2013. The Mental Life of the Architectural Historian: Re-opening the Early Historiography of Modern Architecture. Newcastle upon Tyne: Cambridge Scholars Publishing. Original edition 2011.

Hitchcock, Henry-Russell. 1928. Modern Architecture: The Traditionalists and the New Tradition. The Architectural Record, no. 4 (April): 337-349.

-1928. Modern Architecture: The New Pioneers. The Architectural Record, $\mathrm{n}^{\circ} 5$ (May): 453-460.

1942. Some Problems of the Interpretation of Modern Architecture. Journal of the Society of Architectural Historians 2, no.2 (January): 29$32,40$.

1968. Modern Architecture: A Memoir. Journal of the Society of Architectural Historians 27, no. 4 (December): 227-233.

Lipstadt, Hélène. 2006. Celebrating the Centenaries of Summerson and Hitchcock: Finding a Historiography for the Architect artHistorian. In Frank Salmon, ed. Summerson and Hitchcock: Centenary Essays on Architectural Historiography, 331-350. London and New Haven: Yale University Press.
MacDougall, Elisabeth Blair, ed. 1990. The Architectural Historian in America: A Symposium in Celebration of the Fiftieth Anniversary of the Founding of the Society of Architectural Historians. Washington: National Gallery of Art.

Montaner, Josep Maria. 2013. Arquitectura y Critica. Barcelona: Gustavo Gili.

O'Neal, William B., ed. 1965. Hitchcock, Gropius, Johnson, Early Virginia. American Association of Architectural Bibliographers. Charlottesville: University Press of Virginia.

O'Neal, William B. 1968. Henry-Russell Hitchcock: The Fourth Decade. In Hitchcock, Magazines, Adam, Vaux, Aalto. American Association of Architectural Bibliographers volume 5 . Charlottesville: University Press of Virginia.

Salmon, Frank. 2006. Introduction. In Frank Salmon, ed. Summerson and Hitchcock: Centenary Essays on Architectural Historiography, XIII-XXX. London and New Haven: Yale University Press.

Scrivano, Paolo. 2000. Hitchcock's Humanism: Some Notes on Two Seminal Books, review of Modern Architecture: Romanticism and Reintegration and The International Style by Henry-Russell Hitchcock, Design Book Review 41/42 (Winter/Spring): 80-83.

Scully, Vincent. 1993. Foreword. In Modern Architecture: Romanticism and Reintegration. New York: Da Capo Press.

Searing, Helen, ed. 1982. In Search of Modern Architecture: A Tribute to Henry-Russell Hitchcock. New York and Cambridge: Architectural History Foundation y MIT Press.

Searing, Helen. 1990. Henry-Russell Hitchcock: The Architectural Historian as Critic and Connoisseur. In Elisabeth Blair MacDougall, ed. The Architectural Historian in America: A Symposium in Celebration of the Fiftieth Anniversary of the Founding of the Society of Architectural Historians, 251-263. Washington: National Gallery of Art.

Segal, Walter. 1974. Review of Modern Architecture: Romanticism and Reintegration by HenryRussell Hitchcock. The Architectural Review, no. 155: 66

Stonorov, Oscar Gregory. 1930. Review of Modern Architecture: Romanticism and Reintegration by Henry-Russell Hitchcock. The Architectural Record, no. 6 (June): 586.

Summerson, John. 1987. "Obituary: Henry-Russell Hitchcock". The Architectural Review, volume 181 no. 1083 (May): 4.

Tournikiotis, Panayotis. 1999. The Historiography of Modern Architecture. Cambridge, MA.: The MIT Press.

Watkin, David. 1980. America. In The Rise of Architectural History. London: The Architectural Press. 34-48.

Wilton-Ely, John. 1976. Review of Modern Architecture: Romanticism and Reintegration by Henry-Russell Hitchcock. Apollo, no. 104: 419-420.

Fecha de entrega del artículo: 14/04/ 15

Fecha de aceptación:

$01 / 07 / 15$

Artículo sometido a revisión por dos revisores independientes por el método doble ciego. 